TITLE:

「教授学、カリキュラムに出会う

」プロジェクトの到達点--アメリ

カのカリキュラム研究とドイツ教 授学の結節点をめぐって--

$\operatorname{AUTHOR}(\mathrm{S})$ :

市川, 和也

CITATION:

市川,和也、「教授学、カリキュラムに出会う」プロジェクトの到達点--アメリカのカリ キュラム研究とドイツ教授学の結節点をめぐって--. 京都大学大学院教育学研究科紀要 2020, 66: $15-28$

ISSUE DATE:

2020-03-26

URL:

http://hdl.handle.net/2433/250364

RIGHT: 


\title{
「教授学、カリキュラムに出会う」プロジェクトの到達点 ーアメリカのカリキュラム研究とドイツ教授学の結節点をめぐって一
}

\author{
市川 和也
}

\section{1.はじめに}

20 世紀末以降、英米圈のカリキュラム研究 1 においてはドイツ語圈を中心とした教授学 (Didaktik)（以下、ドイツ教授学とする）に注目が再び集まっている。後述するが、カリキュ ラム研究において世界的にも著名な学術誌Journal of Curriculum Studies では 90 年代以降、教授 学の文化圏にあるドイツ語圈やスカンディナヴィア諸国の教育研究が、英米圏のカリキュラム 研究との対比の中で盛んに紹介されている。この契機となったのが教授学とカリキュラム研究 の比較研究を行った「教授学、カリキュラム研究に出会う(Didaktik Meets Curriculum)」グルー プ（以下、「出会う」グループとする）である。

「出会う」グループの研究は主にアメリカのウェストベリー（Ian Westbury）、ドイル（Walter Doyle)、ノルウェーのグンデム (Bjørg Gundem)、ドイツ語圈を中心に国際的に活動するキュン ツリ（Rudolf Künzli）とホプマン（Stefan Hopmann）、欧米で研究を行っているガドモンズドッ ティル（Sigrun Gudmundsdottir）らを中心に進められた。この研究は、ドイルの持ってきたドイ ツの数学教育に関するある論文を見たウェストベリーが、1990 年のオスロ大学での学会でホプ マン、グンデムと話すなかで「教授学とは何か」と尋ねたことがきっかけとなって始まった2。 「出会う」グループの活動は主に、(1)グループの中心メンバーによる研究交流、(2)カリキュラ ムの伝統と教授学の伝統の交流を行う国際会議の開催、(3)先述の Journal of Curriculum Studies や学術雑誌 Bildung und Erziehung などへの論文寄稿、(4)ドイツ教授学に関する主要文献の英訳、 (5)両伝統の接続に関する解説である³。この成果は(a) Didaktik and/or Curriculum（1995 年），(b) Didaktik and/or Curriculum: An International Dialogue（1998 年）, (c) Teaching as Reflective Practice - The German Didaktik Tradition（2002 年）などにまとめられている。

日本では「出会う」グループの研究成果を上記の著書をもとに中野和光が 2002 年という早い 段階ですでに紹介しだ。そこでは、同グループに参加したリード（William Reid）やカンサネン

(Perti Kansanen) など、個別の参加者の整理をもとにドイツ教授学が解釈学的アプローチを用 いる一方で、アメリカのカリキュラム研究がテイラー（Frederick W. Taylor）の科学的管理法に 由来をもつ経験科学的アプローチを用いることが紹介され、両者の違いが明らかになった 5 。 かし、アメリカ側の参加者がカリキュラム研究のどのような背景のもとで、ドイツ教授学の何 に注目したのか、また、出会いの中でドイツ教授学とアメリカのカリキュラム研究は両者の間 によ゙のような結節点を見いだしたかという点については詳細に論じられていない。 
論を先取りするが、1995 年に Journal of Curriculum Studies の特集で「出会う」グループによ つて紹介され、その後の議論の中心の 1 つとなったのはクラフキー（Wolfgang Klafki）の「授 業準備の核としての教授学的分析（Didactic analysis as the core of preparation of instruction）」 ${ }^{6}$ で あった。そこでクラフキーは「今日のドイツにおいてもっともよく知られ影響力のある教育者」 であり、「ドイツの教育史に深く根差した伝統を代表する」人物として紹介され、「教授学的分 析（didactic analysis）」を提唱した上記の論文が英訳された7。「出会う」グループでは、例えば ウェストベリーや、ショーマン（Lee Shulman）とともに授業研究を行ってきたガドモンズドッ ティルらがクラフキーの教授学的分析とアメリカのカリキュラム研究や授業研究との結節点を 見いだそうとしている。本稿はそうした結節点を見いだそうとする英語圈の研究者の議論を検 討し、到達点と課題を明らかにする。また、中野が論文を発表した 2002 年においては「出会う」 グループの研究が出版されて間もない時期であったため、その後の研究の展開をフォローする ことが出来なかった。本稿では対話に参加したキュンツリの論考を検討することによって、対 話での議論がドイツの教育課程論の議論においてどのように発展しているかを検討する。

\section{2. アメリカにおけるカリキュラムの伝統とその課題}

まず、「出会う」グループの中心メンバーたちが有していたアメリカの教育観を検討する。ウ エストベリーは教育行政の観点から教師の役割の変遷について説明する。ウェストベリーによ れば、19 世紀前半のアメリカの公教育制度は急速な人口増加に対応する必要があったため、モ ニトリアルシステムなど効率のよい教育方法や学校制度の実現が焦眉の課題となった8。そこで カリキュラムは標準化され、カリキュラムについての意思決定は教師の手から離れ、もっぱら 教育行政官によってなされていたという9。またドイルとウェストベリーによれば、20 世紀前 半に活躍したボビット（John F. Bobbitt）とチャーターズ（Werrett W. Charters）のカリキュラム 研究によって特に社会効率主義的なカリキュラム作成方法や自然科学的手法が生み出され、専 門家や教育行政官がこの方法を用いて科学的にカリキュラムを作成し、学校や教師へのコント ロールを正当化していった ${ }^{10}$ 。したがって、アメリカでは伝統的にカリキュラムの作成主体は 教育行政官や専門家であり、それに対応してカリキュラム研究において教師は「システムの見 えない代行人 (agents)」であり、「明白な役割をもつ独立したアクターではなかった」という ${ }^{11}$ このように 19 世紀から 20 世紀初頭のアメリカでは自律的にカリキュラムを作り、創造的に授 業を行う者としての教師像は軽視されたという。

また、「伝統的なアメリカの教育科学の多くの形態のいずれもが、教育的熟考に対する出発点 として『学校の教科』もしくは『授業内容』に対して注意をまじめに払ってこなかった」12とド イルとウェストベリーが述べるように、アメリカの教育科学において教科や授業の内容も軽視 されたという。彼らは、教科教育に関する研究と教育心理学との関係を検討したショーマンに もとづきながら、授業に関するアメリカの教育科学研究の歴史を振り返る。ショーマンによれ ば 70 年代および 80 年代初頭で最も活発で生産的であった授業研究は、「過程一産出モデル

(Process-Product Research)」にもとづく研究アプローチであった ${ }^{13}$ 。ドイルらはショーマンのこ の概観をもとにソーンダイク（Edward L. Thorndike）やジャッド（Charles Judd）により進めら れてきた授業に関する教育科学研究を取り上げる。ソーンダイクらがそうであったように当時 
のアメリカでは行動主義心理学の発展に伴って、授業研究は授業内容を効率的に伝達するため の最良な方法について、さまざまな条件を制御することによって明らかにする実験的手法を用 いたものが多かった ${ }^{14}$ 。これによってアメリカでは授業が心理学の言語で記述され、目に見え る教師の行動や教授方法が注目される一方で、カリキュラム研究が対象としてきた授業内容、 生徒、カリキュラムは授業の「変数（Variablen）」として無視されたという15。

しかし、行動主義心理学は 50 年代末に始まった認知革命によって批判された ${ }^{16}$ 。認知革命が 進むなかで授業研究において教師の思考プロセスに関する研究が行われるが、ショーマンによ ればそうした研究においても「教科内容 (subject matter content)」と「教科内容に関する理解と 生徒に行う教授との関係」への着目がなされていなかったことを指摘し、両者に関する教師の 認知的理解を明らかにするという研究課題を示した ${ }^{17}$ 。

ドイルとウェストベリーは、この背景のなかで出されたショーマンの「授業における教材の 知識（pedagogical content knowledge）」（以下、PCK とする）によってアメリカの授業研究にお いて教科内容に注目が集まったと評価する。ショーマンはこの PCK を「独自の教師の職能であ る、内容と教授法 (pedagogy) から成る特殊な混合物であり、自らの専門的理解の特別な形式」 18 と定義した。さらに、彼の PCK においては教師がさまざまな知識を、実施されるカリキュラ ムに「翻案する (transformieren)」という意味で、教師はカリキュラムに影響を与える存在とし て位置づけられると整理する ${ }^{19}$ 。このようにドイルらは特にショーマンに基づきながら、教育 内容を注目するに至る経緯や教師がカリキュラム作成主体として登場する流れを取り上げた。

また、ガドモンズドッティルは、1992 年の Bildung und Erziehung においてショーマンをドイ ツ語圈に向けて紹介した。ガドモンズドッティルはショーマンの「教育学的推論と活動モデル (Modell des pädagogischen Denkens und Handelns)」の過程について、「教師が主題もしくは題材 を理解し、目標や教科の構造を取り出し、教科の対象物の内部もしくは外部にある関連する考 えを突き止めようとするカリキュラムのテクスト（Text）とともに始まる」20と述べる。なお、 「テクスト」についてガドモンズドッティルは、「広義の解釈学的概念と一致して、文字に限定 されないありうる授業の素材を代表している」と述心、教育学的推論と活動モデルの出発点に 解釈学的アプローチを位置づける21。また、彼女によれば、教師の知識に注目するという構想に よって、「教師が授業しているカリキュラムやテクストを教師自ら独自の価值や思考と結びつ けることが起こる解釈学的・省察的活動として授業を記述する」22ことが可能となったという。 このようにガドモンズドッティルに紹介されるショーマンの教育学的推論と活動モデルは、教 師が独自に教材やカリキュラムに解釈を加える思考活動として記述されている。

ショーマンが紹介される際、ペレイラ（Peter Pereira）によってアメリカのカリキュラム研究 者であるシュワブ (Joseph J. Schwab) もドイツに紹介された。ペレイラによればシュワブが 1969 年に「実践的であること（The Practical）」という論文で当時のカリキュラム研究を「瀕死」と 形容した際に、(1)タイラー原理を機械的に解勫したグループ、(2)パイナー（William F. Pinar）ら に代表される批判的アプローチをとるグループが存在した ${ }^{23}$ 。ペレイラによればシュワブは第 三のアプローチとして現れたという24。シュワブは上記の背景の中で、「理論的であること（the theoretic)」から「折衷的であること（the eclectic）」「実践的であること（the practical）」へ転回 する必要性を述べる25。シュワブによればカリキュラム研究において多くの理論は実践から離 
れた狭小な枠組みでしか用いられておらず、わずかな理論ですべてが解決されてしまうような 過度な単純化をするか、より抽象的な議論を志向することが多かった ${ }^{26}$ 。こうした実践の軽視 に対してシュワブは「実践的であること」を求める。「実践的であること」とは、「相対的に学 問的なもの（the academic）とは親和性がなく、理論的なディシプリンとは根本的に異なるよう な複雑なディシプリン」であり「理論的であることが知識と関わるのとは対照的で、選択と行 為に関わるディシプリン」である27。シュワブはカリキュラムを例に「実践的であること」を説 明する。カリキュラムは、理論的なものではなく、具体的な教室で行われる一回限りの授業と 関係する。カリキュラムが実行される際に、カリキュラムの理論が現実の生徒や教師に適用さ れるためには、「実践的であること」のアートが求められる 28 。のアートには、教師が具体的 状況に理論を適用する能力が前提とされており、これによりカリキュラムが現実に適合すると いう29。ここではショーマンの場合と同様に、教師が創造的に授業を作り出す主体として描か れている。

「出会う」グループのアメリカ側の研究者は、ショーマンやシュワブを中心にアメリカの状 況をまとめることによって、教師による解釈を前面に出す形で授業研究やカリキュラム研究の 歴史を紹介した。しかしながらドイルとウェストベリーによればアメリカでは伝統的に、「学習」

「指導」「動機付け」のような心理学のコンセプトが授業の基本理解に影響を与えているという 30 。さらに教育行政など、アメリカの教育科学を取り巻く構造的条件は世紀の初めから本質的 に変わってはいないという31。このように「出会う」グループにおいては、当時の心理学や教育 科学とは異なり、教師の実践を尊重したショーマンやシュワブの研究を紹介寸るものの、アメ リカのカリキュラムの伝統では学校行政とそれを支える教育科学によってもたらされる限界性 が絶えず付きまとうものとして認識されていたといえる。後述するように、こうしたアメリカ の議論の取り上げ方は、一特にウェストベリーにおいては一ある種意図的なドイツの教授学の 受容の仕方につながるのである。

\section{3. ドイツ教授学の紹介とその受容}

本節では英語圈におけるドイツ教授学の紹介と受容について検討する。ドイツの教授学

（Didaktik）は、「軽荗的な意味を込めて実践的方法的問題に言及寸る、いくぶん時代遅れの意 味を持っている」英語の“didactics”と異なり、教えること以上の意味合いを有しているという32。 すなわち、(1)研究領域を意味する理論的・研究的レベル、(2)授業、教育課程作成のす心゙ての領 域などを構成する実践的レベル、(3)教師同士の会話や授業準備などの際に「参照枠組み」とな っているレベルである33。このようにドイツ教授学は研究領域として存在するだけではなく教 師が授業を構想する際に機能し、さらには「参照枠組み」として学校関係者の共通言語となっ ているが、一方で教授学は英語圈ではほとんど知られておらず、英語圈にとっては未知の伝統 となっていた ${ }^{34}$ 。しかし、「英語圈のカリキュラムの伝統内部でうまく定義されていないが最も 重要であり、普遍的で教育的なある問いを強調するような思考方法を、教授学が提供する」と ウェストベリーが述べるように、教授学がカリキュラムの伝統の未発の契機を示すと考えられ ていた 35 ここではドイツ教授学がどのように取り上げられたか検討する。

まずウェストベリーの整理にもとづいてドイツにおける伝統的な学習指導要領である「レー 
アプラン (Lehrplan)」について説明する。レーアプランは現代においては州の学習指導要領と して教育内容を提示する文書である。レーアプランそれ自体は 19 世紀初頭以降、学校において 教えられるべき教科や内容を規制する一連のガイドラインとして機能していた 36 。しかし、こ のレーアプランの枠内で教師は「教授学の『アート』において培われた思考方法」または Bildung 概念によってレーアプランに記載される教育内容を解釈し、教育内容に生命を吹き込むことが 求められていたという37。また、教師はレーアプランに記載された教育内容に対して解釈を行 えるだけの「教授の自由」が伝統的に保障されており、アメリカの意味でのカリキュラムによ るコントロールから外れているとウェストベリーは述べる38。このように「出会う」グループに おいてはアメリカのカリキュラム研究を相対化するものとして教授学を位置づけた。

しかし 60 年代以降にアメリカのカリキュラム研究を受容したロビンゾーン (S. B. Robinsohn) は、教授学が推し進めてきたレーアプラン論では、教育内容を決めるらえで合理的手法が用い られていないことを指摘し、その結果ドイツ語圈を中心に英米のカリキュラム研究に影響を受 けたカリキュラム運動 (Curriculumbewegung) が生じた ${ }^{39}$ 。英米のカリキュラム研究が英訳され 普及するなかで、60 年代の終わりにはほとんどだれもが、精神科学的教育学

(Geisteswissenschaftliche Pädagogik) やその核心である教授学の没落を疑わなかったという40。 しかし、ロビンゾーンが構想したカリキュラム改革は中央集権的に行われるものとして考えら れ、教師は改革の内容を末端で実行する存在として位置づけられている41。こうした上意下達 のプロセスは、州レーアプランから一定程度独立して学校や教室でローカルな授業計画を作成 するドイツの学校行政や教授学にふさわしくなかった ${ }^{42}$ 。したがって、ウェストベリーが述べ るところの「システムの見えない実行者」として教師を捉えるという意味でのカリキュラムの 伝統は、そのアイデンティティを失うことなしにはドイツの体制に受け入れられず、しばしば 教師の自律性の文脈で批判されていった ${ }^{43}$ 。こうしてホプマンらが指摘するようにカリキュラ ム運動は、「瀕死」となるのではなく、年いもなく静かに亡くなってしまったのである ${ }^{44}$

一方で、ホプマンとリクォーツ (Kurt Riquarts) によればカリキュラム運動で批判された教授 学は二つの点で変化したという 45 。第一に、州レーアプランのコントロールに対して無批判で あったというカリキュラム運動からの批判を受け入れ、州のコントロールが生徒にとって望ま しくないものであれば、批判的に抵抗するというコンセンサスが生まれた。第二に、教科の枠 組みからレーアプランの内容や目標を問い直す教科教授学が大学や教師教育において拡大した 46 。このように教授学はドイツにおいてカリキュラム研究の批判を受けながらも再びドイツの 教育研究の中心的役割を担うようになった。

こうした教授学の最も普及しているモデルとしてクラフキーの教授学的分析が挙げられる。 先述のホプマンとリクォーツによれば、60 年代には教授学的分析がすでに広まっており、教授 学に代わろうとするカリキュラム研究を失速させるほど強力なものだったという47。ここでは クラフキーの教授学的分析がどのように紹介されたかを検討する。クラフキーは、初等教育や 中等教育、教員養成大学での教師の経験をもとに教授学的分析を構想した 48 。この論文の枠組 みは 1958 年にドイツ語で出版されるとドイツ教授学の重要な源泉と位置づけられ、ドイツの 教員養成課程にいるほぼすべての学生に紹介されているという49。また、こうして広められた 教授学はドイツの教育に浸透する一つの「言語（language）」となっているという50。なおクラ 
フキーが精神科学的教育学から批判的構成的教育科学 (kritisch-konstruktiver Erziehungswissenschaft）に移行するなかで彼の教授学も変遷し、一部改訂された。特に批判的構 成的教育科学において Bildung の内容は「自己決定能力」「共同決定能力」「連帯能力」の連関 として捉えられている51。しかし彼によれば初期の中心的アイデアは有効であり続けていると いう52。ここでは 1995 年の Journal of Curriculum Studies において英語で紹介された教授学的分 析を取り上げ、それに対する英語圈の研究者の反応を検討する。

クラフキーによれば授業準備の目的は次のように要約できる。すなわち、「準備は、ある生徒 が行う何らかの教育内容（Bildungsinhalte）との実りある出会いに対する一つの、もしくはいく つかの機会のデザインとして意図されている」53。一方でドイツ語圈では「教育内容」だけでは なく、「教育内容の本質 (Bildungsgehalt)」という語も用いられる。「教育内容」は、教師が準備 をする以前にすでに存在し、文化のなかから選択されたものである。これは例えばレーアプラ ンにおいて教えるように示された教材であり、教師は「教育内容」としてこれらがなぜ選択さ れたかといら点について省察しなければならない54。これに対して「教育内容の本質」は教育内 容に内在するものである ${ }^{55}$ 。しかし「教育内容の本質」は客観的に存在するのではなく、特定の 生徒にとっての意味と関連させ、過去や未来を念頭に置きながら特定の人間的・歴史的状況に 位置づけることによってはじめて理解される ${ }^{56}$ 。このように、「教育内容の本質」を理解するた めには「教育内容」それ自体に多方面からの検討が必要とされる。この検討において必要とさ れるのが教授学的分析である。表 1 に教授学的分析の基本的問いを示す。この問いに沿って具 体的な生徒や時代状況、社会との対応の中で「教育内容」を解鄱することが求められている。

\section{表 1 教授学的分析の 5 つの問い}

I .この内容はどのような幅広い意味、一般的な意味、もしくは現実の範例となり、学習者 に対して開示するか? どのような基本的現象もしくは基礎的原則、どのような法則、規 準、方法、技術、態度がこの内容を「範例」として扱ったときに獲得されるのか?

II. この主題を通して獲得されるべき、問題となっている内容、経験、知識、能力やスキル は教室の子どもたちの精神においてどんな重要性を保有しているのか? 教育的な見地 からこの内容はどんな重要性を有しているのか?

III. 何が子どもの未来に対する主題の重要性を構成するのか?

IV.（問いＩ、II、IIIによって特に教育的見方のなかに位置づけられる）内容がどのように 構成されているか?

V . これらの問いによって決定される内容が「獲得された」と考えられ、「不可欠で」「役立 つ」人間の財産として考えられるならば、保有されなければならない知識の本体（「最低 限の知識」）はなんであるか?

(Klafki, Wolfgang, "Didactic analysis as the core of preparation of instruction (Didaktische Analyse als Kern der Unterrichtsvorbereitung)”, Journal of Curriculum Studies, vol.27, No.1, 1995, pp.22-28 をもとに筆者作成。)

教授学的分析は、非ドイツ語圈においては上述のようなカリキュラム研究のみならず、授業 研究の文脈において特に受容された。先述のガドモンズドッティルは主にショーマンと比較を しながらクラフキーの教授学的分析を検討する。ガドモンズドッティルによれば「ショーマン は、アングロサクソン的教育研究コミュニティを特徴づける経験的伝統の方法にもとづいてい る。クラフキーの枠組みはドイツ教師教育において広く用いられているものの経験的というよ 
りもより哲学的でテクスト的（textual）である」と研究方法論上の相違を述べる57。しかしなが ら、経験的アプローチと解釈学的アプローチの違いはあるものの、両者の結節点としてガドモ ンズドッティルは両者が教育内容に注目していることを挙げている。特にガドモンズドッティ ルはクラフキーの教授学的分析で挙げられる 5 つの問いがショーマンのモデルと同様に、教え られるべき内容とともに出発することを挙げる 58 。上記のようにクラフキーの教授学分析は、 生徒にとっての内容の意義や歴史的状況との関連性などを問うものである。その際、クラフキ 一のアプローチにおいて、テクストに関する教授学的解釈は、なぜ特定の内容がすべての可能 な文化物のなかから選び出され、なぜ教育対象となるかという理由に焦点を当てなければなら ない、とガドモンズドッティルは述べる59。このようにガドモンズドッティルにおいては教育 対象として選ばれるその理由を再度問い直す姿勢を解釈学的アプローチとして捉え直している。

以上のようにドイツ教授学がどのように英米圈に紹介されたかという点に言及してきた。先 述したように、カリキュラム研究の伝統におかれている研究者にとって教授学は、カリキュラ 厶研究の問題、寸なわち教師の実践に対寸る軽視という問題を解決するための道具とみなされ ていた。教育科学が盛んなアメリカにとって教師の実践の取り上げ方が問題になるなかで、ま さに教授学、特にクラフキーの教授学的分析が注目されたと言える。

この「出会う」グループの対話以後、世界のカリキュラム研究は「国際化 (internationalization)」 していく。パイナーは、2000 年に行われたルイジアナ州立大学での「カリキュラム研究国際化 会議（Internationalization of Curriculum Studies Conference）」の内容をまとめた著書において、ア メリカのカリキュラム研究が自国の枠組みに留まり、他国を参照しないナルシシズムを有して いることを指摘した ${ }^{60}$ 。そのうえでこの会議では「カリキュラム研究に関する世界規模の領域 を形成する」こと、すなわち「国際化」を推し進めることが目的とされた ${ }^{61}$ 。なお、パイナーは、

「出会う」グループが開いた 1995 年ノルウェー・オスロでの会議を、パイナーらの取り組みの 先行事例としてみなし、「世界的なカリキュラム研究領域がいつか発展するならば、1995 年 8 月のオスロで始められたと言われるであろう」 62 と、その研究方法の先見性を評価した ${ }^{63}$ 。

一方で、「出会う」グループ、特にウェストベリーの整理に関して、フィンランドのアウティ オ（Tero Autio）は、ウェストベリーが教授学における教師のもつ自由を誇張していることを指 摘する。先述のようにウェストベリーは教授学の伝統における教師の「教授の自由」を高く評 価していた。しかしながらヴェーニガー（Erich Weniger）が指摘するように、レーアプランそ れ自体が国家と緊密に結びついており、さらに教師は国家へ進んで貢献してきた ${ }^{64}$ 。アウティ オはこの指摘を参照しながら、ウェストベリーが国家的性格を内在しているレーアプランの枠 内で教師の有する自由を考えるべきであったことを指摘する ${ }^{65}$ 。先述のようにウェストベリー はアメリカのカリキュラム研究の課題を乗り越えるために教授学の伝統における教師の自律性 や創造性を強調してきたが、アウティオはこの伝統の背後にある国家の存在を指摘し、ウェス トベリーの教師の自由を前面に出寸捉え方に疑問を呈した。なお、パイナーは、ウェストベリ 一が教授学における教師像に希望を見いだす一方で、ホプマンとリクォーツはそうした希望を 明言せず、ほのめかすにとどまっていたことを指摘する66。このように「出会う」グループ内部 においても教授学の捉え方が多様であり、特にウェストベリーにおいてはアメリカのカリキュ ラム研究の背景から、教師の自律性や創造性を特に強調する形で教授学を捉えたと言える。 


\section{4. ドイツ教育課程研究によるカリキュラム研究の受容}

次にドイツ語圈がカリキュラム研究をどのように受け取ったかを検討したい。特にカリキュ ラム研究から影響を受けた例としてPISA ショック後のキュンツリを取り上げる。まず PISAに ついて概説する。ドイツは OECDによる PISA（2000）以後、成績の低迷から PISA ショックを 経験した。これによりドイツでは「コンピテンシー（Kompetenz）」や「教育スタンダード

(Bildungstandard)」に関する議論が盛んになった。ここでのコンピテンシーは心理学者のヴァ イネルト（Franz E. Weinert）によってドイツ語圈に向けて次のように定義された。すなわち、 「個人において意のままにできるもしくは個人を通して習得できる、ある問題を解決するため の認知的能力・技能であり、問題に関連した、意欲的・意識的・社会的な構えや能力があり、

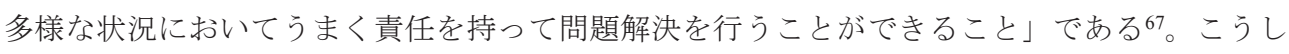
た能力観を基盤として教育スタンダードが作成される。連邦教育・研究省（Bundesministerium für Bildung und Forschung) の報告書では教育スタンダードの機能としては、(1)学校を、コンピ テンシーモデルにもとづいた拘束力のある目標に対して方向付けること、(2)教育スタンダード に基づいて学習結果を把握し、評価することが挙げられている ${ }^{68}$ 。このように教育スタンダー ドが導入されることで、従来の州のレーアプランによるインプットの管理から、教育スタンダ ードに基づくアウトプットの管理へと転換した ${ }^{69}$ 。

ここではドイツ教授学の前提となっていたレーアプランの位置づけが変化し、レーアプラン によるインプット管理から、教育スタンダードに基づくアウトプット管理へと移行した。それ によってレーアプランの枠内で自律的・創造的に教育課程や授業を作ってきた教師の位置づけ もまた、大きく変わる。キュンツリによれば、「教育スタンダードとコンピテンシーモデルの導 入と結びついている理論的・実践的な努力はいくつかの点において 70 年代のカリキュラムの 台頭と似ている」70 という。先述のようにロビンゾーンを中心にカリキュラム運動が起き、70 年代にはアメリカの影響を受けて合理的なカリキュラムの作成方法を追求する研究が盛んにな った。一方でアメリカでは、先述のように 1970 年にシュワブはカリキュラム研究が「瀕死」で あることを告げていた。しかし、理論への偏重を批判するシュワブの「実践的であること」は、 研究者による合理的なカリキュラム開発を志向する当時のドイツの潮流に対しては不穏なもの であり、すぐに無視されたという71。

現在、ドイツ語圈ではコンピテンシーモデルに即した授業が行われ、教育スタンダードにも とづいた評価が要請されている。学校や教師が実施する教育課程はコンピテンシーモデルに裏 付けられることによって専門化・科学化される。それによって教育課程開発は、学習心理学や 発達心理学を扱う実験室や専門家集団に外部委託されるという72。また、キュンツリによれば カリキュラム運動と PISA 後の展開ではともに、教育政策、教育行政、教育研究の関係者が科 学的な手法に対して大きな信頼を寄せていることが共通しているという73。このようにドイツ においてはカリキュラム運動が求めてきたカリキュラム開発の合理化がもたらされつつある。 しかし、それによって必然的に授業は、伝統的な教授学が重視してきた実践の文脈や教師の抱 く価值から乘離してしまう。ドイツが抱えるこうした課題は、まさにシュワブが「実践的であ ること」において批判した内容であるとキュンツリは指摘する74。すなわち教育問題の解決は 学習心理学や神経科学における調查や学力測定ではなく、むしろ教育実践の専門家によって試 
市川：「教授学、カリキュラムに出会う」プロジェクトの到達点

みられることがシュワブの議論から明らかになるという75。

このようにキュンツリにおいて PISA 後ドイツの教育政策に対する批判は、シュワブの「実 践的であること」における実践的文脈を軽視することに対する批判を援用しながら行われてい る。同様に、キュンツリは学校や教師に求められる実践的活動に関して最も示唆的なものとし てもシュワブの「実践的であること」を挙げる76。現在、教育スタンダードにもとづいて実践を 行うためにドイツの教師は、学校の性格、すなわち学校の文脈、教師の能力、生徒の興味や関 心、生徒の能力、地元の学校環境にあわせた独自の学校教育課程を作成することが求められて いるという77。以上のようにキュンツリは PISA 後の問題を考えるうえでシュワブのカリキュラ ム論を援用している。それによって、コンピテンシーなどの心理学的な専門用語によって語ら れがちな教育課程を再度実践的文脈に位置づけようとしている。このようにキュンツリは PISA によってもたらされた教育問題、寸なわち教師の実践を軽視することという問題への解決とし てシュワブを受容した。この受容は、本来シュワブを受容すべきであったカリキュラム運動の 失敗と結びつけられて行われ、その結果再びシュワブが受容されたのである。

\section{5. おわりに}

本稿では「出会う」グループの研究をもとに、双方が何をどのように受容したかを明らかに した。先述のように英米圈の研究者においては教師の実践が軽視されがちな教育科学研究や力 リキュラム研究の課題を背景に、クラフキーの教授学的分析がショーマンの理論と結びつけら れて受容された。また、教授学の伝統のなかで見いだされた教師の自律性や創造性、教師の専 門性が紹介され、教授学がカリキュラムの伝統の未発の契機を示寸とさえ考えられた。しかし ながら、特にウェストベリーがカリキュラム研究の課題と教授学を結びつけることによって、 教師の自律性や教授の自由が誇張された。一方、ドイツ語圈においてはカリキュラム運動の歴 史にシュワブが位置づけられ、PISA 後ドイツの教育研究を見直す視点とされた。このように双 方がもつ問題背景や、問題解決に資寸る双方の理論的蓄積が結節点として対話が行われたので ある。この対話は、双方の伝統を伝える際にウェストベリーにみられるような誇張がみられた ものの、パイナーが述べるように「国際化」する世界のカリキュラム研究の出発点としても位 置づけられるものである。また Journal of Curriculum Studies で「出会う」グループの “Starting a dialogue”という論文によって開始された両伝統の対話は、“Continuing the dialogue”78 というつ リーセン（Norm Friesen）の 2018 年の論文が端的に表しているように、現在も続いている。こ のように世界規模での対話は継続しており、カリキュラム研究と教授学の更なる交流とその発 展が予想されるであろう。

ところで日本の教育方法学研究は、中野が指摘するように、歴史的にドイツとアメリカ双方 から影響を受けている79。しかしながら、世界の教育研究が言語の壁をまたいで「国際化」して いる一方で、日本の教育方法学研究では、小柳和喜雄が指摘するようにこの対話を取り上げた 中野のような研究を除けば、英米とドイツ語圈を比較するアプローチはこれまで取り上げられ てこなかった ${ }^{80}$ 。世界のカリキュラム研究が「国際化」し、それぞれの理論の相互交流が行われ る状況において、それぞれの地域一筆者の場合は特にドイツではあるが一のカリキュラム研究 の動向をホリスティックに把握するためには、その国の歴史や伝統のみならず、国際的視点を 
踏まえた研究を進めていくことも必要になると思われる。特に PISA ショック以後、ドイツは 英米圈の教育研究に大きく影響を受けている。今後の課題として、そうした教育研究の「国際 化」のなかにあるドイツの教育課程研究の現代的動向を、スタンダードや教育評価に関する英 米での研究成果を踏まえながらより詳細かつ包括的に論じていきたい。

\section{脚注}

1 本稿ではアメリカ由来の概念であることを強調する際には「カリキュラム (curriculum)」と 表記する。カリキュラム一般を指寸場合は「教育課程」、アメリカのカリキュラムと対置され るドイツ固有の教育課程を指寸場合は「レーアプラン（Lehrplan）」と表記する。なお、引用 箇所についてはこの限りではない。

2 Westbury, Ian, Hopmann, Stefan \& Riquarts, Kurt, "Preface", Westbury, Ian, Hopmann, Stefan \& Riquarts, Kurt (eds.), Teaching as a Reflective Practice, New York: Routledge, 2015, pp. ix - x （初出は New Jersey: Lawrence Erlbaum Associates, 2000）（以下、Teaching as a Reflective Practice とする)。

3 Doyle, Walter, “The Didaktik/Curriculum Dialogue: What Did We Learn?”, Uljens, Michael \& Ylimaki, Rose M. (eds.), Bridging Educational Leadership, Curriculum Theory and Didaktik - Nonaffirmative Theory of Education, Switzerland: Springer, 2017, p.220.

4 中野和光「ドイツ教授学と米国のカリキュラム研究・授業研究の出会いと交流」『教育実践 研究』第 10 巻、2002 年、pp.93-97。

5 同上論文、pp.95-96。

${ }^{6}$ Klafki, Wolfgang, "Didactic analysis as the core of preparation of instruction (Didaktische Analyse als Kern der Unterrichtsvorbereitung)", Journal of Curriculum Studies, vol.27, No.1, 1995, pp.13-30.

${ }^{7}$ Keitel, Christine \& Hopmann, Stefan, "Editorial”, Journal of Curriculum Studies, vol.27, No.1, 1995, p.1.

${ }^{8}$ Westbury, Ian, "Didaktik and Curriculum Theory: Are They the Two Sides of the Same Coin?", Hopmann, Stefan \& Riquarts, Kurt (eds.), Didaktik and/or Curriculum, Kiel: Institut für die Pädagogik der Naturwissenschaften, 1995, p.236（以下、”Didaktik and/or Curriculum”とする）.

${ }^{9}$ Ibid., pp.236-238.

${ }^{10}$ Doyle, Walter \& Westbury, Ian: Die Rückbesinnung auf den Unterrichtsinhalt in der Curriculum- und Bildungsforschung in den USA, in: Bildung und Erziehung, 45, 2, 1992, S.144.

${ }^{11}$ Westbury, “Didaktik and Curriculum Theory: Are They the Two sides of the Same Coin?", p.239.

12 Doyle \& Westbury: Die Rückbesinnung auf den Unterrichtsinhalt in der Curriculum- und Bildungsforschung in den USA, S.137.

${ }^{13}$ Shulman, Lee S., "Paradigms and Research in the Study of Teaching: A Contemporary Perspective", Wittrock, Merlin C. (ed.), Handbook of Research on Teaching 3. Edition, New York: Macmillan, 1986, p.9.

${ }^{14}$ Doyle \& Westbury: Die Rückbesinnung auf den Unterrichtsinhalt in der Curriculum- und 
Bildungsforschung in den USA, S.141-144.

15 Ebenda, S.143.

16 佐伯胖「そもそも「学ぶ」とはどういうことか：正統的周辺参加論の前と後」『組織科学』 vol. 48, No. 2, 2014, pp.38-49 を参照のこと。

${ }^{17}$ Shulman, Ibid., pp.23-25.

18 Shulman, Lee S., "Knowledge and Teaching: Foundations of the New Reform", Harvard Educational Review, vol. 57, No. 1, 1987, p.8.

19 Doyle \& Westbury: Die Rückbesinnung auf den Unterrichtsinhalt in der Curriculum- und Bildungsforschung in den USA, S.148.

${ }^{20}$ Gudmundsdottir, Sigrunund \& Grankvist, Rolf: Deutsche Didaktik aus der Sicht neuerer empirischer Unterrichts- und Curriculumforschung in den USA, in: Bildung und Erziehung, 45, 2, 1992, S.178.

${ }^{21}$ Ebenda, S. 185.

22 Ebenda, S. 180.

${ }^{23}$ Pereira, Peter: Eine Einführung in Josph J. Schwabs Theorie curricularer Erörterung, in: Bildung und Erziehung, 45, 2, 1992, S.159-160.

${ }^{24}$ Ebenda, S.160.

${ }^{25}$ Schwab, Joseph J., "The Practical: A Language for Curriculum”, The School Review, vol.78, No.1, 1969, p.1.

${ }^{26}$ Ibid., pp.3-4.

${ }^{27}$ Ibid., pp.1-2.

${ }^{28}$ Ibid., p.12.

${ }^{29}$ Ibid.

30 Doyle \& Westbury: Die Rückbesinnung auf den Unterrichtsinhalt in der Curriculum- und Bildungsforschung in den USA, S.152.

31 Ebenda.

${ }^{32}$ Hopmann, Stefan \& Gundem, B. Bjørg, "Didaktik Meets Curriculum Towards a New Agenda", Gundem, B. Bjørg \& Hopmann, Stefan, Didaktik and/or Curriculum: An International Dialogue, New York: Peter Lang, 1998, pp.334-335 (以下、Didaktik and/or Curriculum: An International Dialogue と する）．

33 Ibid., p.334.

${ }^{34}$ Westbury, Ian, “Teaching as a Reflective Practice: What Might Didaktik Teach Curriculum?”, Teaching as a Reflective Practice, p.15.

${ }^{35}$ Ibid.

${ }^{36}$ Ibid., pp.22-23.

${ }^{37}$ Ibid., p. 17.

38 Ibid. 
39 Hopmann, Stefan \& Künzli, Rudolf: Didaktik-Renaissance. Zu disem Heft, in: Bildung und Erziehung, 45, 2, 1992, S.118.

40 Ebenda.

41 市川和也「S. B. ロビンゾーンによるカリキュラム概念の受容」『京都大学大学院教育学研 究科紀要』第 65 号、2019 年、pp.391-392。

${ }^{42}$ Hopmann, Stefan \& Riquarts, Kurt, "Starting a dialogue issues in a beginning conversation between Didaktik and the curriculum traditions", Journal of Curriculum Studies, vol.27, No.1, 1995, p.7.

43 市川和也「H. v. ヘンティッヒのカリキュラム論 —ビーレフェルト実験学校の構想に焦点 を合わせて一」『カリキュラム研究』第 28 巻、2019 年、pp.30-31。

${ }^{44}$ Hopmann \& Riquarts, "Starting a dialogue issues in a beginning conversation between Didaktik and the curriculum traditions", p.7.

${ }^{45}$ Ibid, p.8.

46 一般教授学と教科教授学については、高久清吉『教授学一教科教育学の構造』協同出版株 式会社、1979 年、pp.241-251 を参照のこと。

${ }^{47}$ Hopmann \& Riquarts, "Starting a dialogue issues in a beginning conversation between Didaktik and the curriculum traditions," p.7.

48 Ibid., p.13.

${ }^{49}$ Keitel \& Hopmann, "Editorial”, pp.1-2.

${ }^{50}$ Ibid., p.2.

${ }^{51}$ Klafki, Wolfgang, "Characteristics of Critical-Constructive didaktik", Didaktik and/or Curriculum: An International Dialogue, pp.311-314.

${ }^{52}$ Klafki, "Didactic analysis as the core of preparation of instruction", pp.13-14.

${ }^{53}$ Ibid., p. 16.

${ }^{54}$ Ibid., p. 17.

55 Ibid., p. 19

${ }^{56}$ Ibid., p.22.

57 Sigrun Gudmundsdottir, "Klafki's Didaktik Analysis as a Conceptual Framework for Research on Teaching", Teaching as a Reflective Practice, p.320.

58 Ibid., p.321.

${ }^{59}$ Ibid., p.323.

${ }^{60}$ Pinar, William F., “Toward the Internationalization of Curriculum Studies”, Trueit, Donna, Doll Jr., William E., Wang, Hongyu \& Pinar, William F., The Internationalization of Curriculum Studies Selected Proceedings from the LSU Conference 2000, New York: Peter Lang, 2003, pp.4-5.

${ }^{61}$ Ibid., p.1.

${ }^{62}$ Ibid., p.3.

63 なお、パイナーは「出会う」グループによる Bildung 概念の取り上げ方が再概念主義の立場 
からすれば不十分であることを述べ、パイナー自身は(1)Bildung が有する意味の歴史的変遷、(2) ジェンダー的構造、(3)ポストモダンにおける Bildung の意義について検討している。Pinar William F., The Character of Curriculum Studies : Bildung, Curere, and the Recurring Question of the Subject, New York: PALGRAVE MACMILLAN, 2011, pp.63-76.

${ }^{64}$ Weniger, Erich, "Didaktik as a Theory of Education", Teaching as a Reflective Practice, p.120.

${ }^{65}$ Autio, Tero, Subjectivity, Curriculum, and Society between and beyond German Didaktik and AngloAmeriacn Curriculum Studies, New York and London: Routledge, 2012, p.4.

${ }^{66}$ Piner, The Character of Curriculum Studies, p.184.

${ }^{67}$ Weinert, Franz E.: Vergleichende Leistungsmessung in Schulen - eine umstrittene

Selbstverständlichkeit, in: Weinert, Franz E. (Hrsg.): Leistungsmessungen in Schulen 2. Auflage,

Weinheim und Basel: Beltz Verlag, 2002, S.27-28.

${ }^{68}$ Bildungsministerium für Bildung und Forschung (Hrsg.): Bildungsforschung Band 1 Zur Entwicklung nationaler Bildungsstandards - Expertise, Bonn, 2003, S. 9-10.

${ }^{69}$ PISA ショック後の教育改革については原田信之「教育スタンダードによるカリキュラム政 策の展開——ドイツにおける PISA ショックと教育改革——」『九州情報大学研究論集』第 8 巻 第 1 号、九州情報大学、2006 年、pp.51-68 を参照のこと。

${ }^{70}$ Künzli, Rudolf: Curriculum und Lehrmittel, in: Andressen, Sabine, Casale, Rita, Gabriel, Thomas, Horlacher, Rebekka, Klee, Sabina Larcher \& Oelkers, Jürgen: Handwörterbuch Erziehungswissenschat, Weinheim und Basel: Beltz, 2009, S.45.

${ }^{71}$ Künzli, Rudolf, "Memorizing a memory: Schwab's the Practical in a German context", Journal of Curriculum Studies, No. 45, 5, 2013, p.671.

72 Ibid., p.680.

${ }^{73}$ Künzli: Curriculum und Lehrmittel, S.45.

${ }^{74}$ Künzli, "Memorizing a memory: Schwab's the Practical in a German context", p.678.

75 Ibid., p.680.

${ }^{76}$ Ibid., p.681.

${ }^{77}$ Ibid.

${ }^{78}$ Friesen, Norm, "Continuing the dialogue: Curriculum, Didaktik and theories of knowledge", Journal of Curriculum Studies, vol.50, No.6, 2018, pp.724-732.

79 中野和光「カリキュラムの教育方法学的研究」日本カリキュラム学会編『現代カリキュラ ム研究の動向と展望』教育出版株式会社、2019 年、pp.292-296。

80 小柳和喜雄「インストラクショナル・デザインとドイツ教授学の類似と差異に関する研 究」『教育実践総合センター研究紀要』第 16 巻、2007 年、p.20。

(日本学術振興会特別研究員 教育方法学・発達科学コース 博士後期課程 2 回生) (受稿 2019 年 8 月 30 日、改稿 2019 年 11 月 11 日、受理 2019 年 12 月 13 日) 


\title{
「教授学、カリキュラムに出会う」プロジェクトの到達点
}

ーアメリカのカリキュラム研究とドイツ教授学の結節点をめぐってー

\author{
市川 和也
}

\begin{abstract}
本稿では 1990 年代にヨーロッパと英語圈で行われた「教授学、カリキュラム研究と出会う」プ ロジェクトの到達点と課題を検討した。本稿では特に教授学とカリキュラム研究がどのように 結びつけられて受容したかに注目した。アメリカの教育科学研究においては 19 世紀以来教師 の実践を軽視する教育科学研究が台頭したという問題背景が存在した。そのため、アメリカは ドイツ教授学における教師の自律性や、教授学の、生徒や歴史的状況、教材など具体的な実践 の文脈に注目する解釈学的アプローチに注目した。その際にアメリカで受容されたのはクラフ キーの教授学的分析であった。また、ドイツ語圈では PISA によって教師の自律性が制限され る中、シュワブの「実践的であること」を受容することで、現在の教育問題に取り組もうとし た。このように双方が抱える問題に対する解決方法がカリキュラム研究あるいはドイツ教授学 のなかに見出され、受容されていったといえる。
\end{abstract}

\section{Research on "Didaktik meets Curriculum" Project: Focus on the Relation between Curriculum Studies and Didaktik \\ ICHIKAWA Kazuya}

This paper clarifies the relation between curriculum studies and Didaktik studies by the "Didaktik meets Curriculum" project performed between Europe and USA in the 1990s. This paper focuses on how Didaktik and curriculum studies were combined and accepted in Europe and USA through this project. In USA, the science of education traditionally neglected practice in the classroom since the 19th century. To solve this problem, researchers from English-speaking countries focused on autonomy of teachers in the Didaktik tradition and accepted an interpretive approach of Didaktik that pays attention to the practical roles of teachers in educational research. Some researchers from English-speaking countries accepted Wolgang Klafki's Didaktik analysis that was widespread in German-speaking countries. On the other hand, in the German-speaking countries, PISA-Shock limited teacher's autonomy by educational standards, and Rudolf Künzli attempted to solve current educational problems by accepting Joseph J. Schwab's concept of "The Practical." This paper clarifies that each researcher accepted solutions to the problems found in curriculum studies or Didaktik.

キーワード：ドイツ、教授学、カリキュラム、レーアプラン、アメリカ

Keywords: Germany, Didaktik, Curriculum, “Lehrplan”, USA 